\title{
REPRENDRE LE DEUXIÈME SEXE
}

This special issue of the Bulletin focuses on Simone de Beauvoir's Le deuxième sexe (LDS), published in 1949. The last few years, especially 1999, have brought a number of articles, books, special journal issues, and conferences on Beauvoir, all of which testifies to a wide sense of appreciation for Beauvoir and her work. Why our issue now, after the celebrations are over? Hasn't everything already been said about Beauvoir and in particular about her most famous book? We don't think so. The point is to engage it. In other words, this is not a belated birthday card. With a growing number of feminist scholars who are part of an international Beauvoir renaissance, we believe that Beauvoir's $L D S$ has not yet been taken seriously enough. ${ }^{1}$

Two factors seem to be most crucially at issue: for one, there is the purely technical matter of the text's inadequate English translation (more on that below). Second and more important, the relationship between feminism and philosophy remains only problematically articulated. This directly affects $L D S$. Reading the dismissive comments by numerous scholars in both fields, it is clear that $L D S$ does not fit either discipline. A queer hybrid, it situates itself elsewhere. To reclaim it, or rather to claim it truly for the first time, would mean to rethink not only the relation between feminism and philosophy but also those fields themselves. This is a project that now seems well under way and it is these conditions that are making possible a new engagement with $L D S$.

But the obstacles are tremendous. For many feminists, Beauvoir's positions are, to say the least, dated and her text deserves attention only as a historical document. Dubbed a "feminist bible," the text was resurrected twenty years after its first publication and helped to consolidate a second wave women's movement whose concerns have now given way to those of a new generation of feminists. Beauvoir's text thus is radical only in the original sense of the word as having been at the origin of a political project that now belongs to the past. Consequently the privileged place for encountering $L D S$ remains the college "History of Feminism" class. Those few feminists who over the years have tried to retrieve $L D S$ from its interment as a historic monument and suggested that we not only read it as an articulation of

${ }^{1}$ See in particular Bauer (2001) and Moi (1999). 
theory but also explore some of its insights as avenues for a revitalized contemporary feminist theory, often encounter strong resistance: "Why go back there? Beauvoir doesn't even like women! Look at her comments on lesbians!" "Go back to her theory of the body? I think we have already done better than that!" "She contradicts herself all the time!" And finally, there always is the ultimate blow, the damning reference to Sartre: Beauvoir would have adopted wholesale Sartrean concepts, and who could ever think Sartre a feminist? As a result, the position Margaret Simons took already in 1979 on the occasion of $L D S$ 'thirtieth anniversary is still provocative:

Beauvoir's analysis of woman's oppression in The Second Sex is open to many criticisms ... Still, we have no theoretical source of comparable scope that stimulates us to analyze and question relentlessly our situation as women in so many domains: literature, religion, politics, work, education, motherhood, and sexuality. As contemporary theorists explore the issues raised in The Second Sex, we can see that in a sense all feminist dialogue entails a dialogue with Simone de Beauvoir. And a discussion with her can be a way of locating ourselves within our feminist past, present, and future. (Simons 8)

Philosophers' hesitations about the status of Beauvoir's text ironically used to crystallize around the same issues that bothered feminists, albeit with a difference: while many feminists consider Beauvoir's positions to be out of date politically, philosophers have tended to see too much politics. The text would more properly belong to sociology. And even when they have acknowledged a philosophic Beauvoir, that Beauvoir more often than not takes the form only of a derivative Sartre. To be sure, today's standard dictionaries and encyclopedias of philosophy no longer outright exclude her, but as a philosopher in her own right Beauvoir still seldom qualifies. In other words, Beauvoir's status as a philosopher is as uncertain as her status as a bona fide feminist.

But things are changing. One sign that a general re-evaluation of Beauvoir as a philosopher is currently under way is the entry on Beauvoir in the new Routledge Encyclopedia of Philosophy (1998). It runs over seven columns and was authored by the Beauvoir scholar Eva Lundgren-Gothlin. Not coincidentally, Lundgren-Gothlin is among the growing number of feminist philosophers whose work is reshaping the 
discipline. One can perhaps discern three distinct ways in which that is happening: as some philosophers import a feminist instrumentarium and use that encounter to further sharpen those instruments, the way Judith Butler does, others recast apparently feminist issues as fundamentally philosophic ones in the manner of, for instance, Nancy Bauer and Debra Bergoffen; still others are inscribing Beauvoir into a philosophic tradition. Hence the unprecedented number of recent studies on Beauvoir as a philosopher. Usually these analyses take the form of identifying lines of influence: who influenced whom? Given the lifelong relationship between Beauvoir and Sartre, his name figures prominently in this discussion: Did Sartre develop his ideas about the Other and his concern with individual socialization during childhood (as in his study of Genet) on the basis of work Beauvoir had been pursuing earlier, or did Beauvoir appropriate Sartrean concepts and ideas? Which is the more original of the two? Recently this pursuit of genealogies has broadened so that Beauvoir now is being connected also to other central modern philosophers such as Descartes, Hegel, Marx, Nietzsche, and Merleau-Ponty. Yet one wonders what this focus on "influence" means. Am I a philosopher by virtue of using other philosophers' ideas as one uses a set of tools? Or am I a philosopher only in the more restricted sense of auctor, to invoke Bourdieu's distinction between the auctor who creates a new idea and the equally necessary but differently charged lector who keeps it alive by teaching others about it? Beauvoir herself had something interesting to say about this. Insisting on the philosophical aspect of $L D S$, she told Margaret Simons in 1985:

... while I say that I am not a philosopher in the sense that I am not the creator of a system, I'm still a philosopher in the sense that I've studied a lot of philosophy, I have a degree in philosophy, I've taught philosophy, I'm infused with philosophy; and when I put philosophy into my books it's because that's a way for me to view the world; and I can't allow them to eliminate that way of viewing the world, that dimension of my approach to women, as Mr. Parshley [the American translator of $L D S]$ has done. (Simons 93)

Clearly, it never occurred to Beauvoir to consider her book as anything other than a philosophical text that broke new grounddespite her assertion in the same breath that she is "not a philosopher in the sense that [she is] not the creator of a system." In $L D S$ she created something else, namely a form that brings into dialogue philosophy and 
women's concrete experience in the service of a larger utopian project of human brotherhood. To get there she had to do more than to repeat the ideas of other thinkers. As Nancy Bauer shows in her recent Simone de Beauvoir: Philosophy and Feminism (2001), Beauvoir's borrowings are appropriations that create genuinely new possibilities.

\section{Virtual Beauvoirs}

When $L D S$ first appeared in France in 1949, it was greeted as a scandal. Not even the circle of leftist intellectuals within which Beauvoir moved could quite stomach her analysis of woman's situation. The story of the two volumes' translation into English is well known: Blanche Knopf, wife of the American publisher Alfred A. Knopf, happened to be visiting Paris during the initial uproar over $L D S$ and brought it back to New York with her. It might produce healthy sales for her husband's firm also, especially since, in Mrs. Knopf's estimation, it "was a modern-day sex manual, something between Kinsey and Havelock Ellis" (qtd. in The Second Sex xiv). It would certainly be popular with the college crowd. Her husband shared her views about potential sales and target audience but complained about the text's length. The author, he opined, "certainly suffers from verbal diarrhea ... I can hardly imagine the average person reading the whole book carefully. But I think it is capable of making a very wide appeal indeed and that young ladies in places like Smith who can afford the price, which will be high, will be nursing it just as students of my generation managed somehow to get hold of Havelock Ellis" (quoted in The Second Sex, xv).

By the time H.M. Parshley- Professor Emeritus of Zoology at Smith College, expert on human reproduction, and frequent as well as competent consultant for scientific translations from French-had completed his translation, the text had become more efficient indeed: charged to cut and condense where he could, Parshley omitted about half of the "History" chapter, almost thirty-five pages of the chapter on marriage and tightened passages elsewhere too. ${ }^{2}$ Initially he tried to discuss these changes with Beauvoir. But not expecting a translation that would be edited and abridged, Beauvoir soon lost interest in the project and effectively stopped communicating with Parshley. Her only consolation now was the money the English translation would bring. Oddly enough changes to the original were not marked at all in the

${ }^{2}$ Simons speaks of a total of "almost a hundred pages [that] were cut from the original French edition" (93). 
translation. Beauvoir had asked Parshley to at least indicate in the "Translator's Note" the fact that changes had been made as well as their extent and to note also that she had strongly objected to all alterations, but the final printed version does not include any such information (Simons 93-94).

If Parshley ultimately lacked control over the resulting text's length and had to accept the publisher's instructions, he is nonetheless directly accountable for the translation's many conceptual problems, which have prompted generations of readers to accuse Beauvoir of conceptual imprecision and to find her text so barren a ground for advanced feminist theory. As a zoologist-even a specialist on human reproduction-but not a philosopher trained in the Continental tradition and familiar with Hegel, Heidegger, and the new existentialism, Parshley could hardly be expected to produce an accurate text. To his credit he tried to do his best by learning about Continental philosophy as he went along. But his reading did not save him from committing sometimes egregious errors that effectively invert Beauvoir's original meanings. As a result, readers of The Second Sex have encountered a palimpsest. A severely distorted version of $L D S$, it lacks in Margaret Simons' words the original's "philosophical integrity" (Simons 93).

Unfortunately problems in translation are the rule rather than the exception with Beauvoir's text. As Anna Alexander reports in this issue, Japanese-language readers found their "Beauvoir" to use "femininity" and "motherhood" interchangeably; Swedish-language readers never even suspected that Beauvoir commented extensively on the lesbian, the mother, and the prostitute, since those chapters had been silently dropped. The fate of $L D S$ in Germany is disturbingly representative. A full German translation was available in West Germany as early as 1951, but like Parshley, the German translator also had trouble recognizing and rendering key existentialist concepts. Existentialism was relatively new then and the attitude toward translation used to be much more relaxed than it is today. Inaccurate translation therefore seemed almost inevitable. It is important to emphasize that this was a global phenomenon that affected all French existentialist texts and did not constitute, as one might perhaps suspect, a sexist response to Beauvoir in particular (a number of important existentialist novels are currently being re-translated because the earlier German translations have proved so deficient). At any rate, Beauvoir's text came out severely distorted. Witness the translation of the text's most famous line, the opening sentence of volume two, "Lived 
Experience." "On ne naît pas femme, on le devient" turned into "Man wird nicht als Frau geboren, man wird dazu gemacht," which effectively erases Beauvoir's central insight and makes her appear to argue its exact opposite. By stressing woman's becoming through socialization and each individual's active participation in that formation, Beauvoir precisely rejects the much more deterministic understanding that speaks out of the form "gemacht." Women are precisely not mere helpless victims, not simple products of the conditions they encounter (which is why Beauvoir thinks historical materialist accounts of women's situation always fall short). Instead, their position is rather more ambiguous and therefore also more hopeful. As Sartre puts it in the volume's epigraph, "A moitié victimes, à motié complices, comme tout le monde." Whatever a woman becomes, she also chooses herself that way. This is of course not an argument for voluntarism but rather one for responsibility and agency, however limited that space for agency may turn out to be for the concrete individual. Beauvoir's women always remain agents; even their most self-defeating behaviors are active choices, free responses to the ever-present temptation to flee one's responsibility and the weight and uncertainty that attach to experiencing oneself as human transcendence. In other words, to choose immanence over transcendence, to accept being man's Other, carries a considerable reward: someone else will justify my existence (LDS I: 21):

Refuser d'être l'Autre, refuser la complicité avec l'homme, ce serait pour elles renoncer à tous les avantages que l'alliance avec la caste supérieure peut leur conférer. L'homme-suzerain protégera matériellement la femme-lige et il se chargera de justifier son existence: avec le risque économique elle esquive le risque métaphysique d'une liberté qui doit inventer ses fins sans secours. En effet, à côté de la prétention de tout individu à s'affirmer comme sujet, qui est une prétention éthique, il y a aussi en lui la tentation de fuir sa liberté et de se constituer en chose: c'est un chemin néfaste car passif, aliéné, perdu, il est alors la proie de volontés étrangères, coupé de sa transcendance, frustré de toute valeur. Mais c'est un chemin facile: on évite ainsi l'angoisse et la tension de l'existence authentiquement assumée. L'homme qui constitue la femme comme une Autre rencontrera donc en elle de profondes complicités. 
But the first German translation effectively erases a take on women's situation that is more complex than invoking overpowering social forces or even juxtaposing deterministic social structures and individual agency. In Beauvoir's model, the individual's agency is also enlisted on the side of unfreedom as women are being tempted into freely consenting to being an Other. Fortunately, a complete, new, critical German translation-one that restores Beauvoir's original meanings and accurately translates the philosophical terminologyappeared in 1992 under the direction of the Beauvoir specialist Irene Selle. ${ }^{3}$ For more on the vicissitudes of the German Beauvoir, see the testimony in this volume by Florence Hervé. How much this new translation has helped to reinvigorate feminist thinking within the German academy seems difficult to gauge. On the other hand, feminist philosophy has clearly been a fast growing area of scholarship. In particular, there is increasing interest in feminist phenomenological approaches to the problem of the body and embodied experience, the very issue that dominates volume two of $L D S$. Which brings us back to $L D S$ in its English incarnation.

${ }^{3}$ Selle, a former East German citizen had been lobbying cultural authorities for years to get $L D S$ published in East Germany. Because official circles were mindful of Georg Lukacs' condemnation of existentialism and did not want to risk offending the French Communist Party, which had so unmistakably rejected $L D S$ immediately following its publication, the state's censorship body blocked the book's publication for almost forty years. Six of Beauvoir's other books had become available between 1967 and 1983. The East Berlin publisher Volk und Welt finally released $L D S$ in the West German translation of 1951 in December 1989, one month after the Wall had come down. But as Selle reports, the fact that Das Andere Geschlecht was not available in bookstores did not prevent its discussion. Academic libraries possessed some French and German copies, and illegally obtained copies circulated in intellectual and oppositional circles. Throughout the 1980s East German women met in church groups to discuss feminist issues and to reflect on what to many seemed steadily consolidating patriarchal structures. That is where many of them encountered Beauvoir. Selle herself traveled between the country's church groups to give lectures and initiate discussion. For more on the hidden history of an East German Beauvoir, see Irene Selle, "Publication et réception du Deuxième sexe en R.D.A.: Compte rendu d'une expérience vécue," Lendemains 94 (1999): 92-101. 
Will H.M. Parshley's text soon be similarly replaced by an accurate translation? We do not know. So far the current copyright holder refuses to bring out a new complete and corrected translation despite heavy and persistent lobbying. Sales of The Second Sex apparently still satisfy the publishers as they can rely on continued steady interest in Beauvoir's book as a historic icon. With the spread of women's studies there will always be something of a demand regardless of the quality of the translation, which is very different from the situation in Germany where women's studies functions differently and where, as Hervé reports in this volume, only some 610,000 copies have been sold over a period of 50 years. Perhaps sufficient then as a historical document, as a text that could give much-needed new impetus to American feminist theory, engage feminist philosophers, and spur wide discussion, the existing The Second Sex is useless. To be sure, crucial passages are appearing in good English translation as more scholars work on $L D S$, but none of that fundamentally changes the need for a complete critical edition. ${ }^{4}$ The good news is that it may finally be on its way. In 1999, the German feminist and scholar Ingrid Galster organized a conference at the Catholic University of Eichstätt as a first step toward realizing that project (see Hervé in this volume). If it succeeds, the English-language scholarly edition will be a collaborative work translated by a large international group of feminists that reads like a who is who of contemporary feminism: Naomi Schor, Margaret Mitscherlich-Nielsen, Elisabeth Roudinesco, Kate Millett, Judith Walkowitz, Elisabeth Badinter, Marie-Jo Bonnet, Margaret Simons, Rita Süssmuth, Alice Schwarzer, Julia Kristeva, Françoise Héritier, and Eva Lundgren-Gothlin among others.

\section{Beauvoir as Avantgarde?}

Let's bracket for the moment the quarrel over whether Beauvoir qualifies as a first-rate feminist theorist or a first-rate philosopher and move instead to two slightly different questions: from a feminist perspective, what does $L D S$ do and why has it been so difficult to see? Let's start with the latter.

Clearly some of Beauvoir's positions do not sit well with many contemporary feminists. As we look at the complaints, we seem to be able to distinguish a common theme that could be captured in a single accusatory phrase: Beauvoir is male-identified and she hates being a

${ }^{4}$ See for example Moi (1999) and Bauer (2001). 
woman. Given what $L D S$ shows about the cultural production of femininity, we think even Beauvoir would agree- but only because these judgments mean one thing against the background of her argument and quite another in a context that remains inscribed with second-wave feminist thought (there is of course a profound irony in the fact that Beauvoir is generally celebrated as the mother of second-wave feminism; on the other hand, the simultaneous absence of serious engagement with her work might also make one suspect that she is merely an honorary mother). Where second-wave feminists would diagnose self-hatred, Beauvoir sees an assertion of transcendence; where the former detect an appalling lack of solidarity, the latter sees only an uncompromising rejection of immanence. Refusing to be a woman, refusing to congeal into an object/Other, and rejecting the prison of femininity, Beauvoir insists on her freedom as a subject that is engaged in a project and a becoming:

Tout sujet se pose concrètement à travers des projets comme une transcendance; il n'accomplit sa liberté que par son perpétuel dépassement vers d'autres libertés; il n'y a d'autre justification de l'existence présente que son expansion vers un avenir indéfiniment ouvert. Chaque fois que la transcendance retombe en immanence il y a dégradation de l'existence en « en soi », de la liberté en facticité; cette chute est une faute morale si elle est consentie par le sujet; si elle lui est infligée, elle prend la figure d'une frustration et d'une oppression; elle est dans les deux cas un mal absolu. Tout individu qui a le souci de justifier son existence éprouve celle-ci comme un besoin indéfini de se transcender. (LDS I: 31)

Is the subjectivity Beauvoir describes here something that necessarily belongs to all men? Only if they are not trapped in inauthenticity, which Beauvoir defines as fleeing the exacting demands of one's freedom and seeking refuge in the certainty of a thing. Woman as Other functions as such a thing for men. Once men realize that any meaning their lives will have they will need to create themselves, that they must define their projects without any guarantees but still in full responsibility, many react with fear and use woman as the Other to regain (a false) solid ground: "pour l'homme pris entre le silence de la nature et la présence exigeante d'autres libertés, un être qui soit à la fois son semblable et une chose passive apparaît comme un grande trésor" (LDS II: 575). In sum, Beauvoir's desire for transcendence is a sign of 
male identification only in an abstract sense since in their concrete lived experience most men recoil from its challenges.

At the same time as many feminists responded with suspicion to what Beauvoir argued in $L D S$ (excepting her immensely useful notion of woman as the Other), they also questioned her method: Beauvoir does not make any appreciable effort to draw on other women's work, at least not when it comes to theory. For that she relies exclusively on male philosophers. The issue came up in a 1979 interview with Margaret Simons and Jessica Benjamin: who were her feminist theory models, didn't she rely also on Virginia Woolf? Beauvoir's off-hand response reveals that this question was foreign to her way of thinking. She had enjoyed reading A Room of One's Own, but relied on it? She also had read To the Lighthouse but couldn't recall it very well...

I cannot say that there was someone in whose path I followed. The closest to me on this plane was, certainly, Virginia Woolf. ... No, I cannot say that I was influenced by anyone in particular in The Second Sex ... Or perhaps I was influenced by everyone. It was my stance with respect to the world and to literature, as I saw them. (Simons 12).

The many women who do appear in $L D S$ serve as informants. They furnish the text's raw material, its evidence: testimony culled from medical reports, diary entries, and women's novels. Beauvoir's women are certainly not silent--their voices are there on every page- - but even though they speak loudly, they speak in a particular mode. One explanation for this appears in $L D S$ itself in a discussion of women's cultural achievements to date: so far there has been no female genius. What is missing is not some secret spring but an attitude that social structures and conventions often obstruct: the attitude of the subject that can throw itself fully into its projects, without worrying over what other people will think, inspired only by the consciousness of its freedom and the desire to realize its transcendence. As Beauvoir puts it, women have remained too caught up in the world of things:

Les restrictions que l'éducation et la coutumne imposent à la femme limitent sa prise sur l' univers; quand le combat pour prendre place dans ce monde est trop rude, il ne peut être question de s'en arracher; or, il faut d'abord en émerger dans une souveraine solitude si l'on veut tenter de s' en ressaisir: ce qui manque d'abord à la femme c'est de faire dans l'angoisse 
et l'orgueil l'apprentissage de son délaissement et de sa transcendance. (LDS II: 555)

Women have not yet come to terms with the fact that they are thrown into the world and must assert themselves as transcendences. Beauvoir directly refers here to Heidegger. Yet she doesn't identify that debt. Nor does she do so elsewhere with other thinkers. Why not? An answer may lie in her understanding of philosophy: "L'art, la littérature, la philosophie sont des tentatives pour fonder à neuf le monde sur une liberté humaine: celle du créateur" (LDS II: 555). As concretizations of human beings' attempts to create the world anew and found it not in matter but on human freedom, philosophy and art become impersonal (or rather not gendered in the way we currently understand that notion). The ideas that allow such a new founding no longer belong to anyone in particular. What will it mean for feminist theorists to adopt this view?

For one thing feminists will be able to confront male thinkers with much less defensiveness and from a position of strength, for even if the sexual politics of a Nietzsche may be offensive to many of us, his project was part of all philosophers' efforts to ground the human in something other than brute nature. And this is a very strong basis for reclaiming some of his thought and rendering it useful for our futures. The whole canon of male philosophers miraculously turned from enemies into co-conspirators? Elizabeth Grosz probably meant something along these lines when she recently challenged feminists to reorient our energies from critique to production. Speaking about "Feminist Futures" and demanding that we rethink the real and the material, that some of us turn our attention to questions of ontology, Grosz promoted what to many feminists would seem "very strange alliances": to positively engage for instance Darwin, Bergson, or Deleuze. Such an encounter with what is "alien" might be most productive to feminism today. ${ }^{5}$ But to move from critique to production also means moving beyond second-wave feminism. After all, critique-the probing for sexist bias of the works of male poets, novelists, philosophers and others, which furnish the conceptual framework through which concrete historical individual experience themselves - was a central aspect of second-wave feminist activity. While certainly necessary, the problem with such critique is that it consigns one to the position of respondent. Beauvoir chose production

5 Elizabeth Grosz, "Feminist Futures," MLA Convention, Washington, D.C., 28 December 2000. 
over critique and so situated herself in a way that would make it harder for second-wave feminism fully to enlist her work on its side. But the situation is different now. Should we add to Grosz's list of candidates for promising new alliances the name of Beauvoir? One thing is certain: Beauvoir has never been a second-wave feminist.

There remains the tricky issue of the text's historicity. Doesn't the very fact that its analysis of the situation of woman is based on the special situation of French bourgeois women of the second third of the twentieth century limit its value? Over the past fifty years their situation clearly has changed dramatically. Also it variously has been pointed out that Beauvoir overgeneralizes, that she doesn't attend to how differences of class, ethnicity, and race affect concrete women's lives - in sum, it would seem that the very sensitivities that feminists today expect of any text are missing from hers. Attention to the demands of historicity then would seem to require one to leave $L D S$ in the safe space of the feminist historical museum where is has been sleeping for so long. We could even enlist Beauvoir's own insistence that one analyze women's "lived experience" against her. But it seems to us that the invocation of historicity doesn't quite address the crucial issue. $L D S$ is precisely not a sociological text. As a philosophical text, defined in the terms Beauvoir outlines above, it reflects on how, for women, the fundamental project of any human being--to inscribe oneself on the world and create meaning - has been thwarted by force and through women's complicity. The human species, Beauvoir insists in the final chapter, is something other than a species; it is a historical becoming and defines itself by how it assumes its natural facticity ( $L D S$ $I I: 560$ ). A profound consciousness of historicity is thus inscribed at the center of the text.

Beauvoir saw $L D S$ as part of a new generation's attempts to understand and analyze women's situation ("un effort de lucidité"; $L D S$ I: 30). What do we stand to gain from a return to it? What can LDS do for a reinvigorated feminism? It seems to us-and the contributors to this volume confirm this-that there are three areas of scholarship in particular that may benefit from a critical re-reading of $L D S$ : the analysis of the body and embodiment; the question of agency; and finally, the question of the subject. For reasons of space we can only sketch here Beauvoir's possible contributions.

Strongly influenced by the phenomenology of Merleau-Ponty, Beauvoir rejects as inadequate any understanding of the body that 
remains based in dualism. The body is neither pure matter, nor instrument, nor a prison. It does have a material dimension but its concreteness consists in the fact that it is our means for understanding the world around us. We perceive the world through and with our body: "Chez les filles et les garçons, le corps est d'abord le rayonnement d'une subjectivité, l'instrument qui effectue la compréhension du monde: c'est à travers les yeux, les mains, non par les parties sexuelles qu'ils appréhendent l'univers" (LDS II: 13). Two points seem worth making: first, the body in Beauvoir's understanding cannot be reduced to sexuality, even if sexuality needs to be considered in any productive account of embodiment (this is, of course, part of Beauvoir's critique of Freud). If sexuality nonetheless appears to function as synecdoche for the totality of the body, is this an instance of what Heidegger means when he argues that an object appears as object only secondarily after the relations of meaning that bring it into the realm of the visible and the experiential have been suppressed? What relations of meaning have been obscured in order for sexuality to emerge that way? What would it mean to restore them to the realm of the visible? Second, Beauvoir's body is both in situation and $a$ situation in itself. In other words, the way I experience the world will inflect my very experience of my body and vice versa. My body thus is a way of living the world and living in it. It is historical in more than the ordinary sense: as my self it continually transforms itself and is a becoming up to my death. It is this understanding of embodiment, this interpretation of femininity as an entire complex of economic, social, psychological, and physical meanings bound up with an individual's concrete choices, that is the subject of volume two of $L D S$, "L’Expérience vécue"_-“Lived Experience," not Parshley's sociologizing "Woman's Life Today."

As we discussed earlier, Beauvoir recasts our ordinary understanding of agency. For her, every individual acts at every moment; it is one of our defining traits as human beings: we do things. Although the circumstances under which we live our lives are not of our choosing, within those limits-whether severely or only moderately constraining - we still choose to do one thing rather than another. As a result, agency is not reserved to describing only that privileged class of actions that express resistance. Nor is it opposed to what we usually call passivity. In fact, Beauvoir spends a good deal of effort describing the many ways in which women are being tempted to forgo their fulfillment as human beings and consent to being an Other. As such an Other_passive, congealed into a quasi object_ - a whole range of 
actions remains open except those that would let her actualize her freedom and make her confront her metaphysical responsibility of justifying her existence. Thus the pertinent distinction is not between agent/active and victim/passive but rather between authentic and inauthentic acts. Both kinds actualize meanings but only the former open existence out to an unknown. (Authenticity, one might want to add, refers to whether I dare to fully assume my humanity; it has nothing at all to do with adhering to the trodden paths of tradition (however defined) and is in fact incompatible with it.)

Beauvoir's perspective on subjectivity offers something productive to current feminist theory also. As she does with regard to the body, here as well Beauvoir rejects a static dualism and highlights relationality: I become a subject only with and through the encounter with another subject, which I thereby make into my object. The other subject does the same with me. In other words, my status as a subject arises only in opposing myself to another consciousness. Alterity thus constitutes a fundamental aspect of human existence and is anchored in our thought as a basic category:

La catégorie de l'Autre est aussi originelle que la conscience elle-même. . . . [L]e sujet ne se pose qu'en s'opposant: il prétend s'affirmer comme l'essentiel et constituer l'autre en essentiel, en objet. (LDS I: 16-17)

What does that mean? For one, it would seem to pull the rug from under the easy denunciation of practices of othering as expressions of false consciousness. Second, as Beauvoir also points out, it destroys as a fiction the notion that reality rests on a Mitsein based on supposedly originary feelings of friendship and solidarity between individual consciousnesses (LDS I: 17).

All this has a profound effect on how we conceptualize groups and their cohesion. If there is no originary solidarity, not even a neutral attitude of indifference but rather a fundamental hostility between individual consciousnesses, groups can only constitute themselves in two ways: either the groupness is violently imposed from the outside, or the individuals who want to constitute themselves into a group must permanently work at producing relations of friendship and solidarity. In other words, sisterhood, one of the cornerstones of much feminist thought, is not a natural phenomenon that can be taken for granted. Jane Gallop recently addressed the issue in her characteristically irreverent fashion and challenged feminists to develop a new model for 
thinking about women's groups that would not just make a space for conflict and struggle between women but treat disagreement as foundational. Sisterhood as we know it projects immediate understanding and shared interests between women; the eruption of disagreement where the ideology of sisterhood foresees only harmony therefore by necessity plunges the group into crisis. Why not abandon the term altogether? Instead of invoking a fantasy sisterhood that hasn't even held up in one's concrete relations with one's biological sisters, feminists could embrace, Gallop suggests, a "rhetoric of difference." Concerted action must be forged in conflict and through negotiation; its conditions of possibility are never just "there." As Beauvoir put it so well, in contrast to the proletariat and Blacks, women historically have had trouble to say "We":

Si la femme se découvre comme l' inessentiel qui jamais ne retourne à l'essentiel, c'est qu'elle n'opère pas elle-même ce retour. Les prolétaires disent «nous». Les Noirs aussi. Se posant comme sujets ils changent en « autres » les bourgeois, les Blancs. Les femmes-sauf en certains congrès qui restent des manifestations abstraites-ne disent pas «nous »; les hommes disent « les femmes » et elles reprennent ces mots pour se désigner elles-mêmes; mais elles ne se posent authentiquement comme Sujet. (LDS I: 18)

Composed by more than a dozen feminists and philosophers from Belgium, Canada, China, France, Germany, the Congo, and the United States, the essays and testimonies in this collection illustrate what kind of work has emerged and continues to emerge from reading and critically re-engaging $L D S$. Our objective, once again, is not hagiography. Rather we want to recover the traces of Beauvoir (as, for example, does Dai Jinhua in her fascinating account of $L D S$ 's unexpected new life in post-socialist China), make visible the text's everyday life, and explore how we can turn Beauvoir's articulation of philosophy and feminism to use for our own times.

University of Minnesota Sabine Engel

${ }^{6}$ Jane Gallop, "Econstructing Sisterhood," The Singer Memorial Conference, Miami University, Oxford (OH), 6 April 2001. 